\title{
INTERNATIONAL FINANCIAL REPORTING STANDARD (IFRS): THE AWARENESS LEVEL IN ACCOUNTING STUDENT
}

\author{
Ayu Aryista Dewi \\ The Faculty of Economics and Business, Universitas Udayana \\ ayuaryista21@gmail.com \\ Luh Gede Krisna Dewi \\ The Faculty of Economics and Business, Universitas Udayana \\ krisna_penindra@yahoo.com
}

Received: October, 2018

Reviewed: April, 2019

Accepted: April, 2019

\section{ABSTRACT}

Changes in accounting standards currently referring to International Financial Reporting Standards (IFRS) require substantive changes at the tertiary level. The purpose of this study is to examine the differences in the level of awareness of accounting students proxied by the level of understanding, knowledge, interest, learning method preferences (pedagogy), and expected expectations (outcomes) of students towards IFRS. Rese arch respondents were S1 students of the Accounting Study Program regular class and an English class. The analysis was carried out through questionnaires. The analysis tool uses independent t-test with the SPSS program. The results of the study indicate that there are differences in the level of interest (interest) and the desired level of expectations (outcomes) in IFRS learning. Research implications are expected to contribute to universities in the preparation of curriculum and formulate learning strategies to improve the knowledge and readiness of accounting students regarding the application of IFRS.

Keywords: IFRS, Interest, Knowledge, Outcome, Pedagogy

How to cite: Dewi, A.A., Dewi., L.G.K. (2019). International Financial Reporting Standard (IFRS): The Awareness Level In Accounting Student. Akrual: Jurnal Akuntansi. 10 (2): 157-176.doi: http://dx.doi.org/10.26740/jaj.v10n2.p157-176

\section{INTRODUCTION}

Accounting is a service activity that aims to provide information which can be used in making economic decision. The accounting environment consists of socio-economic condition, political-legal, restrictions, and various influences from time to time. This resulted the accounting theory evolved to fulfill the needs and influences which continuously changed. One of the changes that occurred in Indonesia was the accounting standards conversion (PSAK) to International Financial

Reporting Standards (IFRS) in 2012.

$$
\text { International Financial Reporting }
$$

Standards (IFRS) is a set of International Accounting standard which is issued by the International Accounting Standards Board (IASB). The aim is to help companies to communicate their financial reports, and to be used by stakeholders to compare the company financial information from all over the world (Helen and Raymond, 2013). Companies that compete in the world market must inevitably 
adhere to financial reporting way according to international standards so that it creates the similarity information from various countries and it is also easy for making economic decision (Flynn, 2008). Some discrepancies that may arise when companies have stated switching to IFRS, but in fact only to choose the part that best suits to the needs in their company (Olson, 2008) .

Financial Accounting Standards (SAK) based on International Financial Standard Report (IFRS) is one of the agreements of the Indonesian government as a member of the G20 forum that has been effectively implemented in Indonesia as of January 1, 2012. Indonesia currently applies Financial Accounting Standards (SAK) per 1 January 2015 which substantially converged with IFRS (effective as of January 1, 2014). The Financial Accounting Standards Board (DSAK-IAI) has committed to maintain the gap between IFRS and PSAK for only one year. The implication, there are many new standards issued by the IASB which will be effective in 2018, must be adopted in Indonesia in 2019. Changes that occur in Indonesia are due to the implementation of IFRS which are expected to facilitate foreign investors in buying or selling their shares in Indonesia. The more similar the reports carried out by companies around the world, the easier it will be to buy and sell shares between Indonesia and other countries.

Indonesia's participation in ASEAN free trade in 2015 as a part of ASEAN Community, also presents its own challenges for accountants to be able to compete with accountants from other countries. Being an accountant as a profession related to these changes is expected to be able to master every standard development that applies in Indonesia, including mastering IFRS. The problem that arises is the concern about the competitiveness of Indonesian accountants globally. Deputy Minister of Finance, Mahendra Siregar in the Indonesian Accountants Association (2013) stated that the competitiveness of accountants in Indonesia is still low compared to accountants of other countries, due to the low awareness of Indonesian accountants to renew accounting sciences, one of which is IFRS convergence in accounting standards finance in Indonesia. Research conducted by (Wahyuni, 2012) also found that public accountants who are not affiliated with foreign parties are not ready for IFRS convergence, although in general Indonesian accountants believe that Indonesia is ready for this change.

Integration of IFRS at the University level also presents its own finds challenges for lecturers and students. The problems are including language and literature, the ability of the teaching staffs, and the level of confidence in the reliability of IFRS in the world of work.

The basic thinking underlying this research is Teory Bloom, which was pioneered by Benjamin S. Bobom. This theory identifies thinking skills ranging from low to high levels which are divided into three domains, namely 
cognitive domain, affective domain and psychomotor domain (Effendi, 2015). Based on this theory, the cognitive domain is indicated by the level of knowledge of students. The higher the level of knowledge students have about IFRS, the higher the level of awareness shown by their willingness to take part in IFRS (affective domain) learning. This will have a practical impact (psychomotor domain) by using IFRS as a standard reference in financial analysis.

Previous research has examined awareness of IFRS convergence included research conducted by Brochet et al., (2011), Soderstrom \& Sun, (2008) suggested that benefits have a positive effect on the willingness to adopt IFRS. Whereas (Zeghal \& Mhedhbi, 2006) states that the level of education has a positive effect on the process of adopting IFRS.

(Barth \& et al, 2008) states that the development of global financial reporting implies the importance of educating students about global financial reports. Accounting students will later become accounting professionals. It is a consideration for universities to plan IFRS integration into the accounting curriculum. This integration must certainly pay attention to ways to develop students' interest in renewing their knowledge. Learning interest is very influential on every action in the learning process (Nuraini, 2007). Interest is the desire of a person or student to explore their knowledge to become a professional accountant. (Christiani, 2015) shows that students' high learning interest will make them more aware in understanding IFRS.

Knowledge about IFRS makes students understand financial information better and the implications of each change in standards. Although not all graduates can be accommodated in companies going public, but the knowledge of IFRS must be owned by every graduate. Accounting students must have knowledge of the implications and application of the latest standards so that after graduation they can become competent resources in global competition.

Widiastuti (2011) revealed that the unpreparedness of accounting students towards IFRS-based changes in IFRSs was also influenced by the unpreparedness of teaching staff, lack of teaching materials, language, and so on. (Helen and Raymond, 2013) study states that reference to learning methods or other terms of pedagogy for IFRS is a more desirable way for someone to achieve goals in learning IFRS. Therefore, the university or teaching staff has an important role in facilitating students by choosing the best approach in IFRS learning.

The development of IFRS-based learning methods is expected to increase student confidence that learning IFRS can be helpful and very useful for them as accountants in the future. In accordance to Warsono (2010), the level of learning expectations (outcomes) that pay attention to IFRS aims to make students have adequate knowledge in accounting that applies in the world of accounting practice. 
Another factor, as expressed by Coetzee and Schmulian (2013); Carvalho and Salotti (2013), one of the factors that causes difficulties for students at universities in South Africa and Brazil in studying IFRS is the language factor. Reference and IFRS materials do not use local languages, this requires accounting teachers to translate them first. This encourages researchers to see differences in perceptions between regular (non-English) class groups and English language classes for the Accounting students towards the development of IFRS-based standards.

Previous studies on student perceptions of IFRS implementation in education tend to be less compared to research on the impact of IFRS on companies and the stock market. Research conducted by Chiang (2013); James and Blaszcyznski (2010) suggested that students realize the importance of IFRS integrated into the accounting curriculum, but students do not have enough knowledge about IFRS. Research by Yoon, Vedd, and Jones (2013) was conducted by assigning employers to give opinions on the importance of students mastering each part of IFRS competencies, the results showed that employers felt the need for students who later worked to understand IFRS. The research conducted by Sugahara (2013), also provides an opinion that is not much different about the importance of convergence in accounting education globally to show that there is uniformity of accounting education in various countries.
In contrast to most studies that tend to see IFRS perceptions in one group of subjects, this study uses subjects consisting of two groups, namely regular grade S1 accounting students and English class accounting program students. Based on the results of Coetzee and Schmulian (2013) and Carvalho and Salotti (2013), language is one of the factors inhibiting students from studying IFRS. So, researchers suspect that familiar English class groups use English in the learning process, have a higher level of awareness of IFRS than regular classes.

Based on this phenomenon, the formulation of the problem in this study is whether there are differences in the level of interest, knowledge, pedagogy, and outcomes of undergraduate program students majoring in accounting after studying IFRS among regular accounting class groups and English class student groups which English class students who have taken financial accounting courses, namely semester 3 and above.

\section{LITERATURE REVIEW \\ International Financial Reporting Standard (IFRS)}

International Financial Reporting Standard or known as IFRS is a set of international accounting standards that aims to create good communication between company management and its stakeholders. IFRS implementation leads to accurate, timely and comprehensive financial statements in accordance with national standards (Madawaki, 2012). According to (Papadatos \& Bellas, 2011), adopting IFRS increases the 
credibility and transparency of financial statements that will contribute to market efficiency. The contribution is expected to be able to make stakeholders make economic decisions from published financial reporting.

The emergence of IFRS cannot be separated from global developments, especially those that occur in the capital market (Herawati, 2011). The rapid development of information technology (IT) in the market environment has had an impact on many aspects of the capital market, ranging from financial reporting models and standards, distance relativism in capital movements, to the availability of information networks throughout the world. The application of IFRS is expected to facilitate foreign investors in buying or selling their shares in Indonesia.

At present, in Indonesia, Financial Accounting Standards (SAK) are effective on $1^{\text {st }}$ January 2015 which substantially converged with IFRS which became effective as of 1 January 2014. The Financial Accounting Standards Board (DSAK-IAI) has committed to maintain the gap between IFRS and PSAK only for one year. The implication, many new standards issued by the IASB which will be effective in 2018, must be adopted in Indonesia in 2019.

\section{Impact of IFRS on Education}

According to Nilsen (2008), IFRS integration will have an impact on the future of accounting information. Preparation for entering IFRS and IAS (International Accounting Standards) into the accounting curriculum has been prepared, but some problems need to be addressed. The main problem is the lack of appropriate course material and the second is an outdated textbook that needs to be updated for IFRS adoption. The right way to transition all U.S. companies to IFRS requires training related to IFRS for investors, management, auditors, and the inclusion of IFRS in the Accounting curriculum (Moqbel \& Bakay, 2010).

IFRS convergence has resulted in many professors having problems in combining IFRS into the current accounting curriculum (Nilsen, 2008). This study identifies several problems in the accounting curriculum suggesting necessary improvements in accounting textbooks. Because students have been taught U.S. standards, transition may be more difficult, and the application of IFRS is probably the biggest accounting change (Olson, 2008). The application of IFRS is a very significant event in the capital market. Many researchers mention the lack of stability of the accounting curriculum as one of the reasons for their concern. The impact of the development of this IFRS convergence on accounting classes is potentially high. Today students must be aware of IFRS, its principles, and its impact on the world of accounting (Paul \& Burks, 2010).

In regarding to accounting education, changes in the IFRS program will be very important. However, there are several obstacles to the application of these standards, which include national and regional differences in the 
interpretation and application of accounting principles and standards Lin \& Wang, 2001); skinner (2013) and various levels of transparency in the process of adoption of IFRS (Steffee, 2009). Although much effort has been made to achieve uniformity, research shows that some countries feel that they do not comply with their current accounting standards, let alone be in a position to adopt international IFRS.

\section{Interest in IFRS}

In this study interest, defined by Skinner (2013) and Widaningrum, et al (2010) as an individual's interest in something and the individual feels happy to be involved in it. If someone has an interest in something then he will give special attention and treatment to it.

According to the Big Dictionary Indonesian language means attention or preference for an object. Djaali (2008) interest is the relationship between yourself and parties outside of ourselves where we feel happy with something. Likewise with Slameto (2010) interest is someone's interest in doing something. Interest is also interpreted as "conditions that occur with feelings of pleasure associated with their own needs or desires" Interest is considered as an intermediary for motivational factors that have an impact on a behavior (Zakari, 2014).

Learning interest is very influential on every action in the learning process (Nuraini, 2007). Matters related to good learning behavior can be seen from the habit of attending lessons, the habit of reading books, visits to libraries and the habit of facing exams. Therefore, learning behavior or good learning interest will lead to an understanding of maximum learning. Conversely, the impact of learning behavior or learning interests that are not good will lead to an understanding of the less than optimal learning. The results of this study are in accordance with the research conducted by (Ishak, 2010) and Atmaja, et al (2017).

Previous research was found by Widaningrum et al (2010) that student learning interest has a positive effect on understanding IFRS. Students who feel interested in the object are IFRS so the student will easily understand IFRS because there is a feeling of pleasure when learning material about IFRS. Research conducted by (Christiani, 2015) shows that student learning interest is high so that students will be more understanding in understanding IFRS.

\section{Knowledge of IFRS}

According to the Big Indonesian Dictionary, knowledge is everything that is known related to something. So, it can be said that the level of knowledge is the level at which someone knows something about something.

The process of IFRS convergence in Indonesia is not an easy thing to implement. Shifting from rule based standards to principal based standards requires a change in mindset among professional accountants. IFRS convergence has also forced students as prospective Indonesian accountants to learn many new accounting standards. This level of 
knowledge in IFRS convergence can be measured by the information obtained in relation to IFRS, understanding the changes in the standards applied.

Previous research conducted by (Helen and Raymond, 2013) only a few students realized that the Accounting Standards Board in Hong Kong adopted IFRS. So, the lack of knowledge of IFRS in education in a country compared to countries that have already adopted IFRS will result in a shortage of quality personnel. Multinational companies and public accounting firms that provide services to multinational entities, as well as organizations that deal with global companies that have not yet adopted IFRS, are expected to seek professional accountants who understand IFRS.

\section{Pedagogy in IFRS}

According to the Big Indonesian Dictionary, preference is the right to take precedence and precedence over others while the method or method is used to do a job in order to achieve something desired. Preference of learning methods or other terms pedagogy (Helen and Raymond, 2013) for IFRS is a more desirable way for someone to achieve goals in learning IFRS.

Based on the research suggestions given by (Barth \& et al, 2008), making education based on IFRS principles is an appropriate learning (pedagogy) as the development of assessment skills. The accounting education literature has identified many skills that are very important for the success of modern accounting professionals (Patro \& Gupta, 2012). These skills include intellectual skills, technical and functional skills, personal skills, interpersonal and communication skills and organizational and business management skills (IAESB, 2010).

(Patro \& Gupta, 2012) research has developed several interventions that can be used by accounting educators to encourage the development of these skills. Examples of these interventions include: simulation and role playing (Sergenian and Pant 1998; Fortin and Legault 2009); problem-based learning (Milne and McConnel 2001; Hansen 2006); cooperative-based learning (Kennedy and Dull 2008; Riordan et al 2008); case analysis with alternative solutions (Boyce et al., 2001). While the research conducted by (Helen and Raymond, 2013) uses various ways to encourage the development of these skills through active learning tasks (Rebele et al., 1998), case analysis in class (Fry et al., 2003), problem-based learning (Hansen, 2006), as well as role and drama simulations (Fortin and Legault, 2009). In making the report, they apply it in their operating environment. Research (Abdullah, Naser, \& Al-Duwaila, 2017) shows that most of them indicated that they obtained information about IFRS from lectures and the internet. Therefore, using a principle-based approach in IFRS learning can help students who will later be involved in the accounting profession.

\section{Outcomes in IFRS}

Warsono's (2010) study states that the level of learning expectations that pay attention to IFRS 
demands is that learners have adequate knowledge in the accounting field that applies in the world of practice, which in turn acts as one of the parties that bring change in the practice world, because the world of practice should follow the academic world. , and not vice versa. The objectives of IFRS include ensuring that the company's interim financial statements for periods are put forward in the annual financial statements; contains high-quality information that is transparent to users or stakeholders and can be compared globally throughout the period presented; provide an adequate starting point for accounting based on IFRS; and provide benefits to users that are greater than the costs incurred. In connection with this, the role of institutions in facing these changes must have a major impact on the development of their knowledge so that they can provide satisfactory outcomes.

Studying IFRS has a lot of benefits which certainly will help prospective accountants in developing their skills in conducting business transactions. Studying IFRS also helps in making management, investment, operational and financial decisions, and in running the business later. Students believe that learning IFRS can help and is very useful for them in making financial statement decisions and functions.

\section{Research Hypothesis}

Based on literature review and previous research, the research hypothesis is as follows: 1) There is difference in the level of interest in IFRS learning between regular class students and English classes, 2)There is difference in the level of knowledge in IFRS learning between regular class students and English classes, 3)There is difference in preference for IFRS learning methods between regular class students and English classes, and 4)There is difference in the level of expectations desired after studying IFRS between regular class students and English classes.

\section{RESEARCH METHOD}

This research was conducted at the Faculty of Economics and Business, Udayana University (Unud). The population in this study are all Accounting Department S1 students who are still undergoing the study period (not alumni) at Unud FEB regular classes and English classes. The chosen population of this study is based on the main reason because accounting students as prospective accountants who later in the world of work will later relate to the presentation of IFRS-based financial statements. So that students are assumed to have awareness of IFRS issues. Data was collected by survey method which is done by distributing questionnaires directly to respondents selected as research samples. Because of the large number of populations, the number of samples is determined using the Slovin formula (Riduwan, 2005: 65). The data analysis technique used in this study is descriptive data analysis techniques and independent t-test independent sample test to examine differences in the level of awareness 
of accounting students towards IFRS among regular class classes and English classes.

Notes:

$$
\mathbf{n}=\mathbf{N} / \mathbf{N}(\mathbf{d})^{\mathbf{2}}+\mathbf{1}
$$

$$
\begin{array}{ll}
\mathrm{n} & : \text { sample } \\
\mathrm{N} & \text { : population } \\
\mathrm{d} & \text { : significant }=0.05
\end{array}
$$

The level of interest is measured by distinguishing student interest in two different groups, namely the regular class and the English class. The questionnaire was used fully adopted from (Helen and Raymond, 2013) instrument, this variable was measured by giving four questions, with a dummy scale of 1 meaningful, and 0 meaningless. The students' knowledge level towards IFRS is how much information obtained that related to IFRS and an understanding of the changes in the standards applied. It is measured by adopting the Helen and Raymond (2013) instrument by asking questions about student awareness of IFRS. The measurement scale uses a dummy variable which means 1 has heard IFRS, and 0 has never heard of IFRS. Then, students are also given questions about how they get IFRS information. Questions are given in the form of closed questions consisting of 4 answer choices. Learning pedagogy preferences are measured by giving respondents four (4) statements in the form of a Likert 1 scale which means that strongly disagreeing to a scale of 5 strongly agrees. (Helen and Raymond, 2013). The desired level of expectation (outcome) is the result or benefit expected by students after studying IFRS in developing skills in accounting. Based on the instrument developed by Helen and Raymond (2013), the desired level of expectation (outcome) is measured by giving respondents seven (7) statements in the form of a Likert 1 scale which means that strongly disagree with a scale of 5 strongly agrees.

\section{RESULT AND DISCUSSION}

The results of the validity of pedagogy and outcome variable explained that the item questions on the pedagogy variable all the validity test results are above 0.30 . This means that each item is able to express something that is measured in the matter. Test of reliability also result Cronbach's Alpha $>0.60$. It indicated that the variables of the questions are reliable.

The population in this study are all Accounting Department students who are still undergoing the study period (not alumni) at the Unud FEB, namely students from 2011-2014. The choice of accounting students as the population of this research is based on the main reason because the role of accounting students in the world of work will be related to the use of the latest Financial Accounting Standards. The population in this study was 670 people. Based on the calculation of the Slovin formula, the number of research samples was 250 respondents consisting of 200 regular class students and 50 English class students. However, not all respondents can complete the questionnaire provided. Only 79.6 percent of respondents met the sample criteria, so the 
number of samples in this study was 199 respondents.

Descriptive analysis aims to find out the description of the research data. In this section, descriptive analysis will be presented based on the minimum, maximum, standard deviation, and averages of each research variable. The following table 1 is the result of descriptive statistics.

Table 1. Descriptive Analysis

\begin{tabular}{|c|c|c|c|c|c|}
\hline & & Interest level (X1) & Knowledge level (X2) & Pedagogy level (X3) & Outcome level (X4) \\
\hline \multirow[t]{2}{*}{$\mathrm{N}$} & Valid & 199 & 199 & 199 & 199 \\
\hline & Missing & 0 & 0 & 0 & 0 \\
\hline \multicolumn{2}{|c|}{ Mean } & 2.68 & 2.76 & 14.60 & 27.70 \\
\hline \multicolumn{2}{|c|}{ Std. Error of Mean } & .050 & .059 & .160 & .284 \\
\hline \multicolumn{2}{|c|}{ Median } & 3.00 & 3.00 & 15.00 & 28.00 \\
\hline \multicolumn{2}{|c|}{ Mode } & 3 & 3 & 14 & 28 \\
\hline \multicolumn{2}{|c|}{ Std. Deviation } & .707 & .836 & 2.260 & 4.004 \\
\hline \multicolumn{2}{|c|}{ Variance } & .500 & 699 & 5.109 & 16.030 \\
\hline \multicolumn{2}{|c|}{ Range } & 4 & 4 & 12 & 24 \\
\hline \multicolumn{2}{|c|}{ Minimum } & 0 & 0 & 8 & 11 \\
\hline \multicolumn{2}{|c|}{ Maximum } & 4 & 4 & 20 & 35 \\
\hline \multicolumn{2}{|c|}{ Sum } & 534 & 549 & 2906 & 5512 \\
\hline
\end{tabular}

Source: Data processed, 2018

Descriptive statistical test results explain the variable interest level has an average value of 2.68 with the lowest value of 0 and the highest value is 4 . The average value obtained from 4 items of questions, if 2.68 for 4 items obtained a value of 0,67 which when rounded to close to the number 1.0 which means that the average response of respondents' perception assessing the interest level variable agrees with the statement given. Knowledge level variable with an average value of 2.76 has the lowest value of 0 and the highest value of 4 . The average value obtained from 4 items of questions, if 2.76 for 4 items obtained a value of 0.69 which when rounded approaching the number 1.0 which means that the average response of respondents' perception assessing the variable statement of knowledge has agreed.
The level of pedagogy with the lowest value of 8 and the highest score of 20 has an average of 14.60 . The average value obtained from 4 items of question items, if 14.60 for 4 items obtained a value of 3.65 which when rounded to close to the number 4.0, which means the average answer to the respondent's perception assesses the pedagogy variable agrees with the statement given .

The outcome level with an average value of 27.70 has the lowest value of 11 while the highest value is 35 . The average value obtained from 7 items of questions, if 27.70 for 7 items is obtained a value of 3.96 which when rounded to close to 4,0 , which means that the average response of respondents' perception assesses the outcome level variable agrees with the statement given. 
The results of testing hypotheses in table 2 describe group statistics between regular classes with English classes in the variable level of interest, knowledge, pedagogy and outcome.

Table 2. Variabel Average Result

\begin{tabular}{llcccc}
\hline & & $\mathrm{N}$ & Mean & Std. Deviation & Std. Error Mean \\
\hline Interest level (X1) & Regular Class & 154 & 2.61 & .698 & .056 \\
& English Class & 45 & 2.93 & .688 & .102 \\
Knowledge level (X2) & Regular Class & 154 & 2.75 & .837 & .067 \\
& English Class & 45 & 2.80 & .842 & .126 \\
Pedagogy level (X3) & Regular Class & 154 & 14.53 & 2.161 & .174 \\
& English Class & 45 & 14.84 & 2.585 & .385 \\
Outcome level (X4) & Regular Class & 154 & 27.34 & 3.835 & .309 \\
& English Class & 45 & 28.93 & 4.356 & .649 \\
\hline
\end{tabular}

Source: Data Processed, 2018

Variable interest rates of 154 regular classes and 45 English classes. The average interest rate for the regular class is 2.61 while the English class is 2.93. Standard deviation for regular class is 0.698 and English discussion class is 0.688. The mean error standard for regular class interest is 0.056 and the English language class is 0.102 .

The level of knowledge in the regular class is 154 people and the English class is 45 people with an average regular class that is 2.75 and the English class is 2.80. The standard deviation for the regular class is 0.837 and the
English language class is 0.842 . The standard error mean for the regular class is 0.67 and the English class is 0.126 .

The level of pedagogy is in the regular class which is 154 people and the class talks about 45 people with an average regular class that is equal to 14.53 and the English class is 14.84. The standard deviation for the regular class is 2.161 and the English discussion class is 2.585. The standard error mean for regular classes is 0.174 and the English language class is 0.385 .

Table 3. Independent Test Result

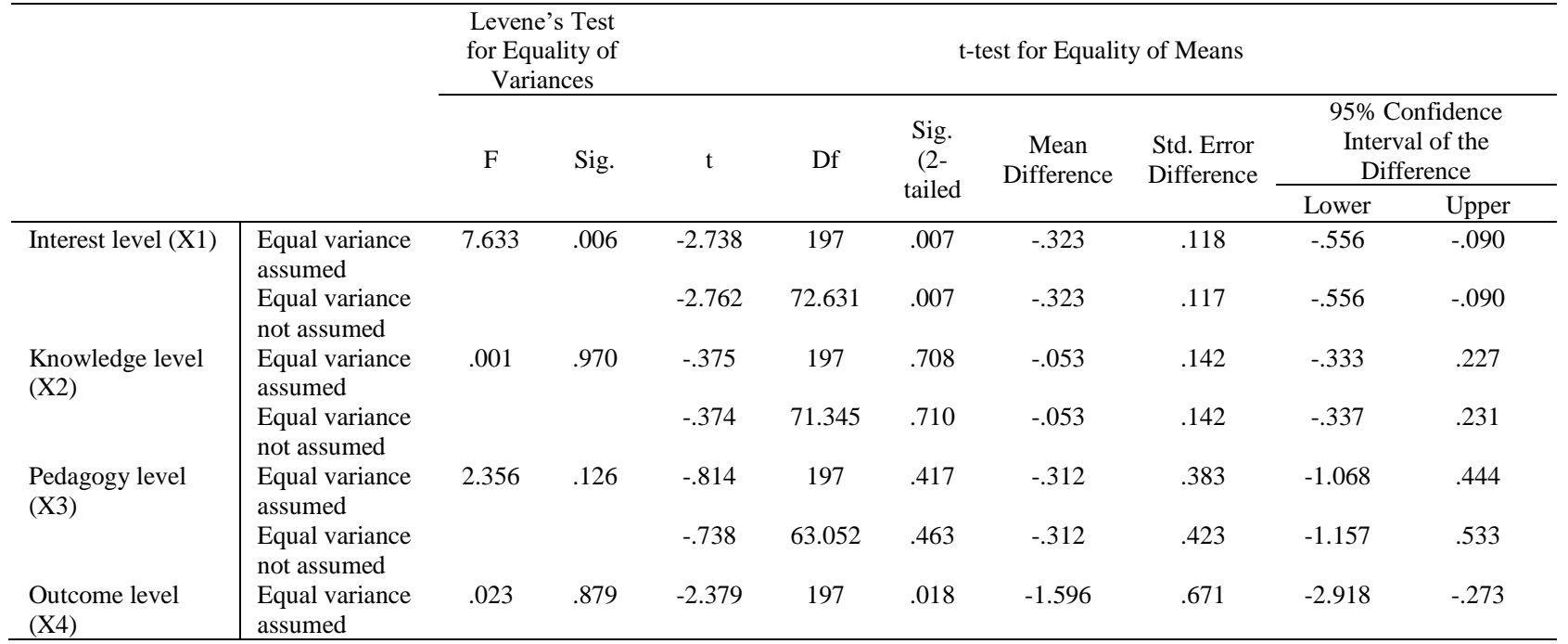


AKRUAL: Jurnal Akuntansi, volume 10, issue 2, April 2019 (157-176)

\begin{tabular}{l|lllllll}
\hline & $\begin{array}{l}\text { Equal variance } \\
\text { not assumed }\end{array}$ & -2.219 & 65.231 & .030 & -1.596 & .719 & -3.032 \\
\hline
\end{tabular}

Source: Data processed, 2018

The outcome level is in the regular class, which is 154 people and 45 students share classes with an average regular class that is equal to 27.34 and the English discussion class is 28.93. Standard deviation for regular class is 3,835 and English discussion class is 4,356. Standard error mean for regular class which is equal to 0.309 and English class is 0.649 .

Table 3 describes the results of Levene's test (homogeneity test) and independent samples test which is used to determine the effect of test scores between the experimental group and the control group. Before conducting the Independent Samples T Test, Levene's test is needed to determine the type of data variant (same or different).

At the interest level it appears that the value of $F=7.633$ with a significance level of 0.006. Because the significance value is below 0.05 , it can be said that there is a difference in variance between regular and English class interest scores. In other words, the interest data between regular and English classes is not homogeneous. Because the data is not homogeneous, it is necessary to pay attention to the sig equal variances not assumed. It appears that the $t$ value is -2.762 with a significance of $0.007(<0.05)$ so it can be concluded that there are differences in the level of interest between regular and English classes and this means that the hypothesis is accepted. It can be seen that the value of $t=-2.762$ (negative) means that the level of interest in the English language class is higher than the regular class which can be seen in the descriptive statistics of the mean column.

Interest or in this study is called interest, defined by Skinner (2006) and Widaningrum, et al (2010) as an individual's interest in something and the individual feels happy to be involved in it. The results of this study are in line with the research of Widaningrum, et al (2010) which explains that student learning interest has a positive effect on understanding IFRS. English class students feel more interested in IFRS compared to regular class students, so they better understand IFRS because there is a feeling of pleasure when learning material about IFRS. This is because English class students are more familiar with IFRS materials that are delivered in English. Conversely, regular class students will feel reluctant to begin to recognize new Financial Accounting Standards, especially with foreign languages. This reluctance will affect every action in the learning process (Nuraini, 2007), which can be seen from the habit of attending lessons, the habit of reading books, visits to libraries and the habit of facing exams. it has been done by (Christiani, 2015), that students' high learning interest will make students understand more about a material, in this research is IFRS material. English class students have a high learning interest, so they are expected to have a maximum understanding of IFRS. Conversely, the reluctance of regular 
class students to lead to learning interests that are not good so that it will impact the understanding of IFRS that is less than optimal.

At the level of knowledge it appears that the value of $F=0.001$ with a significance level of 0.970. Because of the significance above 0.05 , it can be said that there is no difference in variance between the knowledge scores of regular and English classes. In other words, data knowledge between regular classes and homogeneous English. Because the data is homogeneous, it is necessary to pay attention to the sig equal variances assumed. It appears that the value of $t$ is -0.375 with a significance of $0.708(>0.05)$ so it can be concluded that there is no difference in the level of knowledge between regular and English classes and this means that the hypothesis is rejected. It can be seen that the value of $\mathrm{t}=-0.375$ (negative) means that the level of English class knowledge is higher than the regular class which can be seen in the descriptive statistics of the mean column.

According to the Big Indonesian Dictionary, knowledge is everything that is known about something. So, it can be said that the level of knowledge is the level at which someone knows something about something. The level of knowledge in IFRS convergence can be measured by the information obtained in relation to IFRS. This study provides evidence that both regular and English class students have the same level of knowledge about IFRS. Based on the open questions on the questionnaire given to respondents, almost all respondents can fully state the types of Financial Accounting Standards that apply in Indonesia. Likewise with questions about what they know about IFRS, the average respondent knows that IFRS is an international reporting standard that is used as a basis for financial reporting in Indonesia. This gives the assumption that there is no difference in the material given by the lecturer in teaching the two classes.

Pulungan Research (2013) states that even though students understand the importance of IFRS, they feel they do not have adequate IFRS knowledge. If students are interested in this study, it can be said that the learning interest of students in higher English language classes does not necessarily lead to better results or vice versa, low learning interest does not necessarily provide a less than optimal understanding. This can be caused by several factors. First, high student interest is not always accompanied by high academic abilities. Although having a better understanding of foreign languages, but if understanding in accounting, especially financial accounting, the level of understanding will not be maximized. Second, there is still limited literature provided by universities. The university's unpreparedness towards the change of IFRS convergence one of them is not providing IFRS-based accounting literature, which mostly almost uses International language. Third, the ability of lecturers to deliver IFRS material is still not optimal. The shift from rule based standards to principal 
based standards requires a change in mindset among professional educating accountants. This makes lecturers need a longer time to prepare themselves, especially lecturers who teach in regular classes, must first translate IFRS materials into language local. Because this IFRS convergence forces students as candidates for Indonesian accountants to learn many new accounting standards, and also in the two groups have the same teaching facilitator, there is no significant difference in the level of knowledge between regular class accounting students and English classes against IFRS .

At the pedagogy level it appears that the value of $F=2.356$ with a significance level of 0.126 . Because of the significance above 0.05 , it can be said that there is no difference in variance between the scores of regular and English class pedagogy. In other words, data pedagogy between regular classes and homogeneous English. Because the data is homogeneous, it is necessary to pay attention to the sig equal variances assumed. There it appears that the value of $\mathrm{t}$ is -0.814 with sig 0.417 (>0.05) so it can be concluded that there is no difference in the level of pedagogy between regular and English classes and this means that the hypothesis is rejected. It can be seen that the value of $\mathrm{t}=-0.814$ (negative) means that the level of English class pedagogy is higher than the regular class which can be seen in the descriptive statistics of the mean column.

IFRS learning method is a method used to do a job in order to achieve something desired.
Preference of learning methods or other terms pedagogy (Helen and Raymond, 2013) for IFRS is a more desirable way for someone to achieve goals in learning IFRS. Education based on IFRS principles is an appropriate learning (pedagogy) as the development of assessment skills. The accounting education literature has identified many skills that are critical to the success of modern accounting professionals (Patro \& Gupta, 2012). These skills include intellectual skills, technical and functional skills, personal skills, interpersonal and communication skills and organizational and business management skills (IAESB, 2010).

This study revealed that regular and English class students have the same pedagogy, where most students choose pedagogy by searching for IFRS information through lecturer lectures and the internet. This is consistent with the research of (Helen and Raymond, 2013). While some other students want pedagogues to learn through active learning assignments or case analysis in class, as mentioned in the research of Rebele et., Al (1998), and Fry et., Al 92003). Sehin

At the outcome level it appears that the value of $F=0.023$ with a significance level of 0.879 . Because of the significance above 0.05 , it can be said that there is no difference in variance between the regular and English class outcome scores. In other words, outcome data between regular classes and homogeneous English. Because the data is homogeneous, it is necessary to pay attention to the sig equal variances 
assumed. There is a $t$ value of -2.379 with sig $0.018(<0.05)$ so it can be concluded that there are differences in the level of outcome between regular and English classes and this means that the hypothesis is accepted. It can be seen that the value of $\mathrm{t}=-2,379$ (negative) means that the outcome level of the English language class is higher than the regular class which can be seen in the descriptive statistics of the mean column.

Students believe that learning IFRS can help and is very useful for them in making financial statement decisions and functions. The benefits of studying IFRS include helping prospective accountants in developing their skills in conducting business transactions. Other benefits include assisting in management, investment decisions, operational and financial decisions, and in running the business later.

The results also show the value of $\mathrm{t}=-2.379$ (negative) which means that the level of expectation (outcome) of the English language class is higher than the regular class. This is evidenced by the responses of respondents regarding the reasons for studying IFRS. English class students do not just consider IFRS knowledge as part of the learning process, but they hope further, namely making IFRS understanding as a provision for competing in the ASEAN Economic Community (AEC). In connection with this, the role of institutions in dealing with these changes must have a large impact on the development of their knowledge so that they can provide satisfactory outcomes.
Some English class students also gave the reason that understanding IFRS would lead them to opportunities to work in multinational companies, even working abroad. This can be a signal that they are sensitive to the development of accounting science that requires companies that have gone public using international reporting standards. This is in line with Warsono (2010) which states that outcomes that focus on IFRS are intended for students as prospective accountants, to have the ability to compete with other state accountants in global competition.

\section{CONCLUSIONS}

Based on the results of the study, it can be concluded that there are differences in the level of interest (interest) and the desired level of expectations (outcomes) in IFRS learning, where the level of interest and outcomes of English classes are higher than regular classes. This is influenced by several factors, including the language and literature, the ability of the teaching staffs, and the level of confidence in the reliability of IFRS in the world of work. However, the level of knowledge and preferences of the learning method (pedagogy) between regular class students and English language classes do not have a significant difference due to the equality in the provision of materials by the facilitator (lecturer), and there is no difference in the choice of learning methods between the two groups. Students can use learning methods either with active learning methods such as case analysis in class or lecture 
lectures or independent learning methods with information from the internet in understanding IFRS.

Because of the importance of integrating IFRS into accounting education, the suggestion that can be given to educational institutions or universities is to continuously increase students' awareness about the development of Accounting Standards by participating in developing learning methods (pedagogy) and outcomes in studying IFRS, especially for Accounting students. The importance of understanding IFRS in the global world requires every educational institution to revise and update the curriculum, learning methods, and reading sources that refer to the current accounting standards in Indonesia, namely IFRS-based Financial Accounting Standards. Another research implication, for further researchers to be able to continue the analysis of IFRS by using other variables besides the variables that have been examined and using other subjects, such as lecturers or accountants who directly use IFRS in their daily lives. For accountants and other financial practitioners, IFRS can assist in developing skills in conducting business transactions in a global environment, such as management decisions, investment, and making operational and financial decisions.

\section{REFERENCE}

Abdullah, A., Naser, K., \& Al-Duwaila, N. (2017). Students' Attitudes towards the Adoption of International Financial Reporting Standards (IFRS) in Kuwait. Ccsenet.Org. 13(5). 85-95. https://doi.org/10.5539/ass.v13n5p85
Atmaja, R., Ramantha, I. W., \& Suartana, I. W. (2017). Pengaruh Minat Belajar pada Pemahaman Akuntansi dengan Kecerdasan Emosional dan Spiritual sebagai Pemoderasi. 5. 2021-2046.

Barth, M. E. (2008). International accounting standards and accounting quality. Journal of Accounting Research. 46(3). 467-498. https://doi.org/10.1111/j.1475679X.2008.00287.x

Brochet, F., Riedl, E. J., Brochet, F., Jagolinzer, A., \& Riedl, E. J. (2011). Mandatory IFRS Adoption and Financial Statement Comparability Mandatory IFRS Adoption and Financial Statement Comparability. Harvard Business School.

Carvalho, L.N. \& Salotti, B.M. (2013). Adoption of IFRS in Brazil and the Consequences to Accounting Education, Issues in Accounting Education, vol.28 no. 2, pp.235- 242.

Chiang, B. (2013). IFRS in the Akuntan Publik. Mutual Perspectives, Business and Management, vol.6, no.2, pp.1-8. Accounting Perceptions Convergence

Christiani, Y. N. (2015). Pemahaman Mahasiswa Akuntansi Terhadap Internasional Financial Reporting Standar (IFRS).

Flynn, T. (2008). US warming to IFRS as it moves on from GAAP. http://www.ft.com/cms/s/0/e944709e-7a1911 dd-bb93000077b07658.html?nclick_check $=1$

Fortin A., \& Legault M. (2009). Development of Generic Competencies: Impact of a Mixed Teaching Approach on Students' Perceptions. Accounting Education: An International Journal. In Press, Corrected Proof.

Fry H., Ketteridge S., \& Marshall S. (2003). A Handbook for Teaching and Learning in Higher Education: Enhancing Academic Practice. 2nd ed., New York: Routledge.

Hansen J.D. (2006). Using Problem-based Learning in Accounting, Journal of Education for Business, 81(4), 221-224. http://dx.doi.org/10.3200/JOEB.81.4.221224 
Dewi\&Dewi, International Financial Reporting Standard...

Helen, W., \& Raymond, W. (2013). An Empirical Study - Adoption of International Financial Reporting Standards (IFRS) in Hong Kong Education. Journal of Management Research. 5(4). 98.

https://doi.org/10.5296/jmr.v5i4.4256

International Accounting Education Standards Board (IAESB). (2010). International Education Standard IES 3 Professional Skills and General Education. New York, NY: IFAC

Ishak, P. (2010). Pengaruh Kecerdasan Emosional, Kecerdasan Spiritual Dan Minat Belajar Terhadap Pemahaman Akuntansi.

James, M.L., \& Blaszczynski, C. (2010). Accounting Students' Perceptions of International Financial Reporting Standards, Journal for Global Business. 10(2). 37-49.

Lin, Z. J., \& Wang, L. (2001). Financial disclosure and accounting harmonisation: Cases of three listed companies in China. Managerial Auditing Journal. 16(5). 263273.

Madawaki, A. (2012). Adoption of International Financial Reporting Standards in Developing Countries: The Case of Nigeria. International Journal of Business and Management. 7(3). 152-161. https://doi.org/10.5539/ijbm.v7n3p152

Milne, M. J., Phillip J.MC. (2001). Problembased learning: a pedagogy for using case material in accounting education. Accounting Education Journal. 10(1).

Moqbel., \& Bakay. (2010). Are US academics and professionals ready for IFRS? an explanation using technology acceptance model and theory of planned behavior. Journal of International Business Research, 12(2). 47-61.

Nilsen K. (2008). On the Verge of an Academic Revolution: How IFRS is affecting Accounting Education. Journal of Accountancy.

Nuraini, M. (2007). Pengaruh Kecerdasan Emosional Dan Minat Belajar Mahasiswa Akuntansi Terhadap Tingkat Pemahaman Akuntansi. Maya Nuraini. Jurnal Beta. 5. 4-9.
Olson S. (2008). Firms Preparing for New Standards.http://www.ciotoday.com/story.xhtml?story_id=11100A YSS1TF\&page $=1 \&$ full_skip $=1$

Papadatos., \& Bellas. (2011). The Value Relevance of Accounting Information under Greek and International Financial Reporting Standards: The Influence of Firm - Specific Characteristics. Finance and Economics. 76(76).

Patro, A., \& Gupta, V. K. (2012). Adoption of International Financial Reporting Standards (IFRS) in Accounting Curriculum in India-An Empirical Study. Procedia Economics and Finance. 2. 227236.https://doi.org/10.1016/S22125671(12)00083-4

Paul, A., \& Burks, E. (2010). Preparing for international financial reporting standards. Journal of Finance and Accountancy.

Effendi, R. (2015). Konsep Revisi Taksonomi Bloom Dan Implementasinya Pada Pelajaran Matematika Smp Ramlan Effendi. Jurnal Ilmiah Pendidikan Matematika. 2. 72-78.

Rebele, J.E., Apostolou, B.A., Buckless, F., Hassell, J.M., Paquette, L.R., \& Stout D. E. (1998). Accounting Edcuation Literature Review (1991-1997). Part II: students, educational technology, assessment, and faculty issues, Journal of Accounting Education. 16(2). 179-245. http://dx.doi.org/10.1016/S07485751(98)00010-4

Sergenian, G., \& Pant, L. (1998). Increasing students professionalism. Issues in Accounting Education. 13(2). 429-442.

Abdullah, A., Naser, K., \& Al-Duwaila, N. (2017). Students' Attitudes towards the Adoption of International Financial Reporting Standards (IFRS) in Kuwait. Ccsenet.Org, 13(5), 85-95. https://doi.org/10.5539/ass.v13n5p85

Amiaty, R. E. (2015). Persiapan Bank Indonesia Dalam Menghadapi Masyarakat Ekonomi ASEAN 2015.

Atmaja, R., Ramantha, I. W., \& Suartana, I. W. (2017). Pengaruh Minat Belajar pada Pemahaman Akuntansi dengan Kecerdasan Emosional dan Spiritual sebagai Pemoderasi, 5, 2021-2046. 
Barth, M. E., Landsman, W. R., \& Lang, M. H. (2008). International accounting standards and accounting quality. Journal of Accounting Research, 46(3), 467-498. https://doi.org/10.1111/j.1475679X.2008.00287.x

Brochet, F., Riedl, E. J., Brochet, F., Jagolinzer, A., \& Riedl, E. J. (2011). Mandatory IFRS Adoption and Financial Statement Comparability Mandatory IFRS Adoption and Financial Statement Comparability. Harvard Business School.

Christiani, Y. N. (2015). Pemahaman Mahasiswa Akuntansi Terhadap Internasional Financial Reporting Standar (IFRS).

Flynn, T. (2008). US warming to IFRS as it moves on from GAAP.। http://www.ft.com/cms/s/0/e944709e7a19-11dd-bb93000077b07658.html?nclick_check=1

Fortin, A., \& Legault, M. (2009). Development of Generic Competencies: Impact of a Mixed Teaching Approach on Students' Perceptions. Accounting Education: An International Journal. In Press, Corrected Proof.

Fry, H., Ketteridge, S., \& Marshall, S. (2003). A Handbook for Teaching and Learning in Higher Education: Enhancing Academic Practice. 2nd ed. New York: Routledge.

Hansen J.D. (2006). Using Problem-based Learning in Accounting, Journal of Education for Business. 81(4). 221-224. http://dx.doi.org/10.3200/JOEB.81.4.221224

Helen, W., \& Raymond, W. (2013). An Empirical Study-Adoption of International Financial Reporting Standards (IFRS) in Hong Kong Education. Journal of Management Research, 5(4), 98. https://doi.org/.5296/jmr.v5i4.4256

International Accounting Education Standards Board (IAESB). (2010). International Education Standard IES 3 Professional Skills and General Education. New York, NY: IFAC.

Ishak, P. (2010). Pengaruh Kecerdasan Emosional, Kecerdasan Spiritual Dan Minat Belajar Terhadap Pemahaman Akuntansi.
Madawaki, A. (2012). Adoption of International Financial Reporting Standards in Developing Countries: The Case of Nigeria. International Journal of Business and Management. 7(3). 152-161. https://doi.org/10.5539/ijbm.v7n3p152

Milne, M. J., \& Phillip J.M.C. (2001). Problembased learning: a pedagogy for using case material in accounting education. Accounting Education Journal. 10(1).

Moqbel, \& Bakay. (2010). Are US academics and professionals ready for IFRS? an explanation using technology acceptance model and theory of planned behavior. Journal of International Business Research. 12(2). 47-61.

Nilsen K. (2008). On the Verge of an Academic Revolution: How IFRS is affecting Accounting Education. Journal of Accountancy..

Nuraini, M. (2007). Pengaruh Kecerdasan Emosional Dan Minat Belajar Mahasiswa Akuntansi Terhadap Tingkat Pemahaman Akuntansi. Maya Nuraini. Jurnal Beta, 5, 4-9.

Olson S. (2008). Firms Preparing for New Standards.

http://www.ciotoday.com/story.xhtml?stor y_id $=11100 \mathrm{~A}$ YSS1TF\&page $=1 \&$ full_skip $=1$

Papadatos, \& Bellas. (2011). The Value Relevance of Accounting Information under Greek and International Financial Reporting Standards: The Influence of Firm - Specific Characteristics. Finance and Economics, 76(76).

Patro, A., \& Gupta, V. K. (2012). Adoption of International Financial Reporting Standards (IFRS) in Accounting Curriculum in India An Empirical Study. Procedia Economics and Finance, 2(January 2005), 227-236. https://doi.org/10.1016/S22125671(12)00083-4

Paul, A., \& Burks, E. (2010). Preparing for international financial reporting standards. Journal of Finance and Accountancy. 
Saito, M., Hiramatsu, K., \& Mayangsari, S. (2012). Accounting Education for the Implementation of IFRS in Indonesia. International Review of Business, 12(22402053), 1-21.

Skinner, B. F. (2013). Ilmu pengetahuan dan perilaku manusia. Yogyakarta: Pustaka Pelajar.

Steffee, S. (2009). IFRS Discrepancies Vary by Country, Company. The Internal Auditor. 66 (4). 13

Soderstrom, N. S., \& Sun, K. J. (2008). IFRS Adoption and Accounting Quality: A Review IFRS Adoption and Accounting Quality: A Review, (June 2013), 37-41.

Sugiyono. (2012). Metode Penelitian Bisnis. Bandung: CV Alfabeta.

Soderstrom, N. S., \& Sun, K. J. (2008). IFRS Adoption and Accounting Quality: A Review IFRS Adoption and Accounting Quality: A Review, (June 2013), 37-41.

Coetzee, S. A., \& Schmulian, A. (2013) The Effect of IFRS Adoption on Financial Reporting Pedagogy in South Africa. Issues in Accounting Education: May 2013, Vol. 28, No. 2, pp. 243-251.

Sugahara, S. (2013). Japanese Academics' on the Global of Accounting Education in Japan, Asian Review of Accounting, vol. 21 no. 3, pp. $180-204$
Wahyuni, N. I. (2012). Dampak Implementasi IFRS Terhadap Pendidikan Akuntansi Di Indonesia, 12-22.

Warsono (2010). Prinsip-prinsip dan Praktik Keuangan Pribadi. Volume 13 no 2.

Widiastuti, H. (2011). Kesiapan Dosen Akuntansi dalam Mengintegrasikan Materi IFRS dalam Mata Kuliah. Fokus Ekonomi, Vol 10 No 3. Desember. Fakultas Ekonomi. Universitas Stikubank Semarang.

Yoon, S.W., Vedd, R., \& Jones, C.G. (2013). IFRS Knowledge, Skills, and Abilities: A Follow-Up Study of Employer Expectations for Undergraduate Accounting Majors, Journal of Education for Business, Vol. 88 No. 6, pp.352-360. Negara, Jakarta.

Zakari, M. A. (2014). Challenges of International Financial Reporting Standards ( IFRS ) Adoption in Libya, 4(2), 390-412.

Zeghal, D., \& Mhedhbi, K. (2006). An analysis of the factors affecting the adoption of international accounting standards by developing countries. The International Journal of Accounting, 41, 373-386. https://doi.org/10.1016/j.intacc.2006.09.00 9. 
AKRUAL: Jurnal Akuntansi, volume 10, issue 2, April 2019 (157-176) 